\title{
TRANSISI KEHIDUPAN EKONOMI MASYARAKAT WISATA KAMPUNG TOPENG, TLOGOWARU, MALANG
}

\author{
Waqi'atul Aqidah \\ Universitas Islam Zainul Hasan Genggong \\ Jl. PB. Sudirman No. 360 Semampir Kraksaan Probolinggo \\ syifabintunahl@gmail.com
}

\begin{abstract}
Desaku Menanti program from Indonesian Ministry of Social Affairs has been implemented by Malang City Social Service in the form of the development tourism village the named is Wisata Kampung Topeng in Tlogowaru, Malang City. This tourism village is realized as an effort to empower homeless people, such as beggars, buskers, and scavengers. These fostered residents are given variety of facilities and social assistance to meet their primary needs. Society is given guidance and assistance in the form of training and funding business. This research uses qualitative method which type is phenomenological research. Determination of research location uses a purposive area method, in Baran Hamlet, Tlogowaru Village, Kedungkandang, Malang City. The research subjects were determined by purposive sampling, Malang City Social Service and Kampung Topeng Tourism Community. Data collection in this study uses interview, observation, and document. Analysis data used by researcher consist of data reduction, data presentation, and conclusion. This community economic empowerment program as intended to improve community welfare and support economic activities of society. In the process of empowerment, the community face economic transition. Various jobs and efforts the have do to improve a better quality of life. The community is able to be more productive in encouraging and more rational in consumption activities. In addition, the ability of the community to prioritize needs appears in better financial management.
\end{abstract}

Key Words: Economic Transition, Empowerment, and Tourism

\begin{abstract}
ABSTRAK
Program Desaku Menanti dari Kementerian Sosial RI telah dilaksanakan oleh Dinas Sosial Kota Malang dalam bentuk pengembangan desa wisata yang diberi nama Wisata Kampung Topeng di Tlogowaru Kota Malang. Desa wisata ini diwujudkan sebagai upaya pemberdayaan para gelandangan, seperti pengemis, pengamen, dan pemulung. Warga binaan ini diberikan berbagai fasilitas dan bantuan sosial untuk memenuhi kebutuhan primer mereka. Masyarakat diberikan pembinaan dan pendampingan berupa pelatihan dan pendanaan usaha. Penelitian ini menggunakan metode kualitatif dengan jenis penelitian fenomenologis. Penentuan lokasi penelitian menggunakan metode purposive area, di Dusun Baran, Desa Tlogowaru, Kedungkandang, Kota Malang. Subjek penelitian ditentukan secara purposive sampling, Dinas Sosial Kota Malang dan Komunitas Wisata Kampung Topeng. Pengumpulan data dalam penelitian ini menggunakan wawancara, observasi, dan dokumen. Analisis data yang digunakan peneliti terdiri dari reduksi data, penyajian data, dan penarikan kesimpulan. Program pemberdayaan ekonomi masyarakat ini dimaksudkan untuk meningkatkan kesejahteraan masyarakat dan mendukung kegiatan ekonomi masyarakat. Dalam proses pemberdayaan, masyarakat menghadapi transisi ekonomi. Berbagai pekerjaan dan upaya telah dilakukan untuk meningkatkan kualitas hidup yang lebih baik. Masyarakat mampu lebih produktif dalam mendorong dan lebih rasional dalam kegiatan konsumsi. Selain itu, kemampuan masyarakat dalam memprioritaskan kebutuhan tampak dalam pengelolaan keuangan yang lebih baik.
\end{abstract}

Kata Kunci: Transisi Ekonomi, Pemberdayaan, dan Pariwisata 


\section{PENDAHULUAN}

Upaya mencapai pemerataan ekonomi masyarakat dapat diwujudkan dengan pembangunan ekonomi daerah melalui pengembangan berbagai program. Mendorong pengembangan Usaha Mikro Kecil Menengah (UMKM) Masyarakat, desa sentra usaha, dan desa wisata. Hal ini tentu bertujuan untuk meningkatkan produktivitas dan kesejahteraan masyarakat, sehingga mampu menguatkan perekonomian Indonesia. Salah satu potensi Negara Indonesia dengan letak geografisnya yang strategis adalah pariwisata. Usaha pariwisata dapat memberikan pamasukan terhadap pendapatan suatu daerah. Pembangunan pariwisata berperan penting terhadap aspek ekonomi, sosial, dan lingkungan masyarakat. Dalam bidang ekonomi, sektor pariwisata menyumbang devisa dari kunjungan para wisatawan mancanegara maupun wisatawan domestik.

Pemerintah mempunyai peran strategis dalam mengupayakan dan mendukung kesempatan luas bagi masyarakat lokal untuk ikut berpartisipasi dalam aktivitas ekonomi melalui pemanfaatan sumber daya lokal berupa pariwisata. Pemanfaatan pariwisata sebagai penggerak aktivitas ekonomi ini dapat dikembangkan dengan konsep ekowisata. Konsep Ekowisata bukan sekedar menawarkan obyek wisata, namun juga mengupayakan aktivitas konservasi lingkungan, pemberdayaan ekonomi masyarakat lokal, dan melestarikan keragaman budaya masyarakat. Konsep pengembangan desa wisata dapat dilihat dari potensi wisata desa dan lingkungannya. Berdasarkan Peraturan Pemerintah (PP) 50 tahun 2010 tentang Rencana Induk Pembangunan Kepariwisataan Nasional Tahun 2010-2025 (Lampiran 1), daya tarik desa adalah segala sesuatu yang memiliki keunikan, keindahan, dan nilai yang berupa keanekaragaman kekayaan alam, budaya, dan hasil buatan manusia yang menjadi sasaran atau tujuan kunjungan wisatawan.

Kota Malang adalah salah satu daerah di Jawa Timur yang kaya akan berbagai objek wisata. Pengembangan desa wisata telah diwujudkan di sebuah kelurahan di Kota Malang, yang merupakan implementasi program "Desaku Menanti” yaitu wisata kampung topeng Malangan di Dusun Baran, kelurahan Tlogowaru, Kota Malang. Program "Desaku Menanti” merupakan program pemberdayaan masyarakat oleh Kementerian Sosial Republik Indonesia dengan membuat sebuah perkampungan baru dengan sasaran para tuna wisma di beberapa kota. Dinas Sosial Kota Malang merelokasi para warga tuna wisma yang terdiri atas para pedagang kecil, pengemis, pengamen, dan gelandangan untuk dibangunkan desa Wisata Kampung Topeng.

Beberapa kegiatan menjadi agenda pemberdayaan desa wisata Topeng tersebut. Kegiatankegiatan itu diantaranya pelatihan keterampilan membuat topeng Malangan, pembuatan wahana wisata dan kebersihan desa, pelatihan produksi kuliner serta pelatihan untuk meningkatkan kemampuan masyarakat menjadi guide wisata dan pemberian edukasi budaya Topeng Malangan kepada para wisatawan. Dengan itu, masyarakat diharapkan mampu memanfaatkan potensi wisata 
sebagai ketersediaan lapangan pekerjaan sesuai kemampuan yang dimiliki, misalnya berdagang makanan dan minuman, menjual produk kesenian topeng, serta barang-barang lain yang dibutuhkan para wisatawan yang berkunjung. Meski demikian, pihak Dinas Sosial tidak membatasi masyarakat untuk berusaha mencari pekerjaan di luar desa wisata tersebut.

Pemberdayaan masyarakat berbasis ekowisata ini sangat relevan sebagai upaya meningkatkan kesejahteraan masyarakat lokal. Sebagaimana penelitian yang dilakukan oleh Jennifer \& Ross (2011), menemukan bahwa konservasi lingkungan dan pemberdayaan masyarakat menawarkan optimisme bahwa perusahaan pariwisata secara sadar membantu melindungi hutan, selaras dengan kebutuhan sosial-ekonomi masyarakat setempat. Selain itu, Kusuma (2017) menemukan bahwa pengembangan desa wisata secara ekonomi \& sosial mampu memberikan kontribusi dalam meningkatkan ekonomi \& kesejahteraan masyarakat, menumbuhkan peluang usaha, dan mengurangi pengangguran masyarakat. Trisnawati (2017) juga menemukan bahwa pemberdayaan masyarakat berbasis potensi lokal efektif dalam pengembangan desa wisata melalui pemberian pelatihan kepada masyarakat.

Namun, Penelitian yang dilakukan oleh Horton (2009) yang menemukan bahwa program ekowisata selain menawarkan peluang yang positif, namun ada saja dampak yang kurang menguntungkan masyarakat. Tentu hal ini ditimbulkan dari berbagai faktor. Salah satunya seperti hasil penelitian oleh Dewi (2013) pada masyarakat Tabanan Bali, dari penelitiannya Dewi menemukan bahwa pengembangan desa wisata belum melibatkan masyarakat lokal karena peranan pemerintah tampak dominan.

Berdasarkan hasi prasurvey yang dilakukan oleh peneliti di lapangan menunjukkan bahwa pengembangan desa wisata belum berjalan sepenuhnya berjalan sebagaimana tujuan yang diharapkan. Dari 38 KK yang terelokasi Dinas Sosial, 6 KK meninggalkan desa tersebut. Hal itu disebabkan masyarakat kurang mampu beradaptasi dengan lingkungan baru karena akses menuju pusat kota cukup jauh. Lahan pekerjaan yang ada di desa wisata tersebut cukup terbatas, terlebih saat wisata sepi pengunjung sehingga usaha dagang mereka juga menurun. Selain itu, pembinaan dan pembuatan karya seni topeng sebagai ikon wisata desa telah mengalami stagnasi, karena ruang pemasaran yang terbatas. Masih melekatnya mindset masyarakat yang 'serba instan', yang menginginkan produknya cepat terjual dan segera menjadi uang/pendapatan.

Selain penguatan ekonomi masyarakat, program pemberdayaan ekonomi tentu juga perlu melakukan pembinaan pola pikir masyarakat sebagai subjek pemberdayaan. Pembinaan sumber daya manusia merupakan aspek penting dalam memperbaiki cara pandang masyarakat dalam upayanya mencukupi kebutuhan hidup. Berdasarkan latar belakang dan penelitian yang relevan, 
penelitian ini dilaksanakan untuk menganalisis dinamika sosial ekonomi masyarakat sebagai implikasi dari implementasi pemberdayaan ekonomi berbasis ekowisata.

\section{METODE}

Penelitian ini menggunakan pendekatan kualitatif dengan jenis penelitian fenomenologi. Jenis penelitian kualitatif fenomenologi merupakan penelitian yang meninjau sebuah pengalaman yang dapat mengungkap suatu fenomena yang diteliti. Penentuan lokasi penelitian menggunakan metode purposive area di Dusun Baran, Desa Tlogowaru, Kecamatan Kedungkandang, Kota Malang. Subjek penelitian ditentukan dengan cara Purposive Sampling yaitu 10 orang masyarakat Kampung Wisata Topeng, Kepala Dinas Sosial Kota Malang, 3 orang anggota Lembaga Kesejahteraan Sosial (LKS) "Insan Sejahtera" selaku tim pelaksana program dan 1 orang Aparat Kelurahan Tlogowaru, Malang. Pengumpulan data dalam penelitian ini menggunakan metode wawancara, observasi, dan dokumen. Analisis data yang digunakan oleh peneliti terdiri atas beberapa tahap, yaitu reduksi data, penyajian data, dan penarikan kesimpulan.

\section{HASIL DAN PEMBAHASAN}

\section{Hasil}

\section{a. Gambaran Umum Lokasi Penelitian}

Pengembangan Kampung Wisata Topeng dilaksanakan oleh Dinas Sosial (Dinsos) Kota Malang atas instruksi dari Kementerian Sosial RI untuk memberdayakan atau menguatkan perekonomian masyarakat. Dinsos Kota Malang mengimplementasikan program Desaku Menanti dengan mengembangkan desa wisata, yaitu Kampung Wisata Topeng. Kampung wisata tersebut terletak di Dusun Baran, Kecamatan Kedungkandang, Kota Malang. Perkampungan berbasis ekowisata tersebut bertujuan untuk memberdayakan ekonomi masyarak gepeng (gelandangan dan pengemis), anjal (anak jalanan), dan pemulung yang tidak memiliki tempat tinggal, agar lebih mandiri sehingga tidak mengemis dan menggelandang kembali.

Luas lahan kampung wisata tersebut sekitar $9000 \mathrm{~m}^{2}$ milik Pemerintah Kota Malang. Terdapat 40 unit (20 couple) rumah warga yang dibangun beserta wahana wisata berlatar Topeng Malangan. Wahana wisata tersebut terdiri atas wahana outbond, flying fox, area camping, media edukasi seni melukis topeng, wahana bermain anak, spot swafoto, toko souvenir dan pujasera. Peresmian Kampung Wisata Topeng telah dilaksanakan pada 14 Februari 2016 dengan ikon dua Patung Raksasa Topeng Malangan, yaitu Panji Asmorobangun dan Dewi Sekartaji. 


\section{b. Karakteristik Masyarakat Kampung Wisata Topeng}

Masyarakat Kampung Wisata Topeng adalah masyarakat yang direlokasi dari beberapa daerah di wilayah di Kota Malang dengan kriteria yaitu warga asli malang, sudah berkeluarga, dan tidak memiliki rumah/tempat tinggal. Mereka adalah para pengemis, anak jalanan, para pengamen, dan pemulung atau para tuna wisma. Para warga tersebut direlokasi untuk diberdayakan oleh pemerintah, sehingga mereka memiliki pekerjaan baru. Diantaranya membuka usaha makanan kecil, membuka jasa bengkel, membuka usaha toko kelontong, membuka jasa pijat, menjadi buruh bangunan, buruh pabrik, serta ikut memelihara dan merawat taman wisata topeng.

\section{c. Lembaga Kesejahteraan Sosial (LKS) "Insan Sejahtera"}

Pembinaan masyarakat Kampung Wisata Topeng dilaksanakan oleh Dinsos Kota Malang bersama Tim Pengelola masyarakat binaan tersebut. Dalam hal ini LKS Insan Sejahtera adalah tim pengelola kampung wisata yang membantu dan mengayomi masyarakat untuk beradaptasi secara sosial dan lingkungan, serta mengembangkan usahanya. LKS Insan memang bergerak dibawah naungan Dinas Sosial Kota Malang yang fokus pada pembinaan masyarakat Penyandang Masalah Kesejahteraan Sosial (PMKS). Berbagai kegiatan telah dikembangkan oleh Tim Pengelola, diantaranya kegiatan bidang pendidikan dan pelatihan, serta pemberdayaan masyarakat. Sebagaimana visi LKS Insan Sejahtera, yaitu mewujudkan masyarakat yang cerdas dan bertanggung jawab dalam membangun bangsa Indonesia.

\section{d. Dinamika Sosial Ekonomi Masyarakat Kampung Topeng}

Berdasarkan data yang diperoleh peneliti dari lapangan, beberapa keluarga menjadi informan penelitian, diantaranya keluarga KK No. 15, KK No. 21, KK No. 10, dan KK No. 02. Peneliti melihat adanya kondisi transisi keluarga tersebut, baik secara sosial, ekonomi, maupun lingkungan. Dalam hal ini peneliti melihat perkembangan atau keadaan masyarakat tersebut pasca atau dalam masa pemberdayaan.

Keluarga (KK) No. 15 adalah keluarga yang berlatar belakang pekerjaan sebagai pemulung barang bekas dan pengemis di beberapa titik lokasi di Kota Malang. Keluarga Bapak Andi ini sempat mengalami masa krisis pada masa awal proses relokasi. Mereka kesulitan mendapatkan pekerjaan untuk menghidupi keluarganya. Tentu ini adalah hambatan utama mereka hidup di lingkungan baru tersebut. Secara sosial, mereka belum bisa sepenuhnya bersosialisasi dengan masyarakat sekitar, sehingga sulit untuk mendapatkan informasi lowongan pekerjaan. Kendala lain adalah bantuan pemerintah yang belum diterima secara rutin. Sedangkan modal usaha yang diberikan pemerintah pun belum mampu dikelola dengan baik, sehingga usaha dagang mereka 
tidak dapat bertahan. Namun, seiring berjalannya waktu mereka dapat beradaptasi dengan masyarakat dan lingkungan sekitar. Hal ini membuat Bapak Andi mampu mendapatkan pekerjaan sebagai buruh bangunan.

Keluarga (KK) No. 21 adalah keluarga Bapak Heri dan Ibu Tri. Keluarga ini dapat menjadi contoh bagi keluarga yang lain dalam hal konsisten berwirausaha. Bapak Heri berjualan tahu tahwa, sedangkan Ibu Tri berjualan mie pangsit dan minuman ronde. Usaha keduanya ini telah dilakukan sebelum mereka direlokasi ke kampung topeng. Namun, mereka mengalami ketidakstabilan modal, sehingga proses berjalannya usaha dagang pun macet. Hal ini membuat Bapak Heri mencari pekerjaan sampingan sebagai pengamen. Sejak menjadi bagian dari masyarakat binaan yang direlokasi di kampung topeng, beliau dapat memulai usahanya kembali, bahkan lebih lancar dari sebelumnya. Hal ini disebabkan adanya modal usaha dari pemerintah yang sangat mendukung perkembangan usaha beliau hingga saat ini.

Keluarga (KK) No. 10 adalah keluarga Bapak Adi dan Ibu Siti. Kondisi ekonomi keluarga ini dapat dikatakan belum stabil hingga saat ini. Ada dua faktor yang menjadi kendalanya, yaitu jumlah anggota keluarga yang cukp banyak dan kondisi kesehatan Bapak Adi yang sakit dan membutuhkan pengobatan rutin. Hal ini membuat keluarga tersebut harus berusaha lebih giat dalam memenuhi kebutuhan hidupnya sehari-hari. Dalam menyikapi hal ini, tim pengelola kampung topeng memberi kesempatan Ibu Siti untuk bekerja di Bengkel Kerja milik Dinas Sosial (diperuntukkan bagi beberapa warga binaan yang memiliki keterampilan memasak). Selain itu, tim pengelola juga memberikan dana usaha dan pendampingan usaha bakso kepada Ibu Siti.

Keluarga (KK) No. 02 adalah keluarga Ibu Kartini. Keluarga ini juga mengalami fase krisis pada proses awal perpindahan. Selain bantuan pemerintah yang pencairannya belum lancar, layanan kesehatan yang jauh juga sulit didapatkan suami Ibu Kartini yang sakit pada waktu itu. Hal ini membuat Ibu Kartini harus lebih giat berusaha memaksimalkan modal usaha yang diberikan Dinsos Kota Malang tersebut. Beliau mengikuti pelatihan usaha bakso dan aneka makanan yang diselenggarakan oleh tim pengelola. Hal itu membuatnya terampil dan mampu berdagang makanan, membuka usaha bakso dan menerima pesanan dari masyarakat. Selain itu, Ibu Kartini juga menjadi buruh di Bengkel Kerja untuk memproduksi aneka jajanan. Ibu Kartini pernah mengakui bahwa pendapatan yang diperolehnya dari mengamen memang lebih banyak, namun beliau menyadari bahwa keluarganya membutuhkan perubahan secara sosial dan ekonomi, agar kondisi mereka dapat menjadi lebih baik di masa depan. 


\section{PEMBAHASAN}

\section{Pemberdayaan Masyarakat Wisata Kampung Topeng}

Implementasi program Desaku Menanti oleh Dinas Sosial Kota Malang diwujudkan dalam bentuk desa wisata bernama Wisata Kampung Topeng Malangan yang terletak di kelurahan Tlogowaru, Kota Malang. Pengembangan desa wisata tersebut selain mengusung konsep ekowisata, juga mengusung konsep budaya Topeng Malangan sebagai ikon budaya masyarakat Kota Malang. Dese tempat relokasi para tuna wisma itu dibangun dengan tujuan menggerakkan semangat wirausaha masyarakat binaan melalui pendanaan dan pendampingan usaha untuk memperkuat perekonomian warga binaan.

Proses awal relokasi warga terdapat $37 \mathrm{KK}$ yang menjadi peserta binaan, kemudian dilaksanakan sosialisasi dan pengarahan awal mengenai tujuan, prosedur, dan teknis pelaksanaan program pemberdayaan tersebut. Disamping itu, warga binaan diberikan beberapa fasilitas dan bantuan rutin dari pemerintah, yaitu Dinas Sosial yang bekerjasama dengan Pemprov, Pemda, dan Pemkot Malang, serta pihak swasta dengan program CSR-nya. Beberapa dunia usaha yang ikut andil dalam sinergi pemberdayaan ini adalah Bank BRI, PT. Indana, dan PT. Pertamina.

Pelaksanaan program pemberdayaan ini membuat masyarakat mengalami suatu transisi kehidupan sosial ekonomi. Hal ini dapat dilihat dari aspek-aspek aktivitas ekonomi masyarakat binaan, diantaranya kegiatan konsumsi, produksi, dan pengelolaan keuangan yang terdiri atas pengelolaan pendapatan dan pengeluaran.

\section{a. Kegiatan Konsumsi}

Aktivitas pertama masyarakat dalam kegiatan ekonomi yang menjadi dasar untuk melihat dinamika ekonomi adalah kegiatan konsumsi. Aktivitas konsumsi inilah yang menjadi dasar bagi masyarakat dalam mengelola keuangan, baik pengelolaan pendapatan maupun pengeluaran. Hal-hal yang mempengaruhi kegiatan konsumsi masyarakat binaan ini adalah variasi dan jumlah kebutuhan. Jumlah kebutuhan yang dimaksud terkait pada jumlah anggota keluarga. Semakin banyak anggota keluarga, semakin banyak pula kebutuhan yang harus dipenuhi, seperti halnya anggota keluarga KK No. 10.

Di sisi lain adanya bantuan berupa rumah layak huni, biaya listrik dan bantuan sembako dapat meringankan beban kebutuhan primer mereka. Namun, sebagaimana hasil wawancara, peneliti menemukan dua realita sikap warga binaan atas bantuan sosial tersebut. Pertama, ada warga yang merasa senang dengan bantuan tersebut, tetapi bersikap pasif dan ketergantungan. Kedua, ada warga yang merasa terbantu dan termotivasi untuk berusaha secara mandiri. 


\section{b. Kegiatan Produksi}

Kebijakan pemerintah untuk merelokasi dan memberdayakan para tuna wisma bertujuan untuk memotivasi warga binaan untuk lebih giat bekerja. Mampu meningkatkan kesejahteraan dengan memberikan beragam bantuan sosial dan pelatihan usaha, agar mereka menjadi lebih mandiri secara ekonomi. Masyarakat diberi bekal keterampilan usaha, disamping diberi kebebasan untuk bekerja sesuai kemampuan masing-masing, asal tidak kembali mengemis dan mengamen di jalanan. Hal ini pun mampu menjadi stimulus bagi warga binaan dalam usaha yang mereka lakukan.

Selain membuka usaha yang didampingi oleh tim pengelola desa wisata, pekerjaan lain yang dilakukan adalah menjadi kuli bangunan, membuka jasa bengkel, jasa pijat, berternak lele, jasa mebel, menjadi buruh pabrik, berdagang makanan, membuka salon kecantikan, dan jasa ojek, hingga ada yang berprofesi sebagai seniman. Peningkatan produktivitas usaha tampak dari keluarga KK No. 21 yang mampu menjalankan usaha secara konsisten. Secara umum, warga binaan tampak lebih produktif dan lebih aktif bekerja/berusaha dibandingkan sebelum mereka direlokasi dalam program pemberdayaan ini.

Program pemberdayaan ini juga melakukan pembenahan mindset atau pola pikir warga binaan yang cenderung instan dalam memperoleh pendapatan, menjadi mau dan mampu berusaha mandiri. Pembinaan pola pikir masyarakat ini selain dengan sosialisasi dan kegiatan motivasi, juga diadakan kegiatan pelatihan usaha. Baik pelatihan usaha pembuatan produk topeng, maupun pelatihan usaha pembuatan produk makanan. Mengubah mindset serba instan memang cukup sulit untuk dialihkan pada kemauan untuk berusaha. Memang hal ini membutuhkan proses dan waktu yang tidak singkat, sehingga pembinaan mental juga perlu dilakukan secara rutin dan berkesinambungan.

\section{c. Pengelolaan Keuangan Masyarakat}

Pengelolaan keuangan masyarakat menjadi salah satu indikator dalam melihat dinamika kehidupan sosial ekonomi masyarakat. Pengelolaan keuangan yang dimaksud adalah pengelolaan pendapatan yang diperoleh maupun pengelolaan pengeluaran yang 
dilakukan masyarakat dalam memenuhi kebutuhan sehari-hari. Dua sub pengelolaan keuangan ini menjadi dasar masyarakat dalam menyikapi keterbatasan ekonomi mereka.

\section{1) Pendapatan Masyarakat}

Pendapatan masyarakat merupakan indikator utama yang dilihat dari terlaksananya program pemberdayaan ini. Perubahan pendapatan yang lebih baik menjadi tujuan dari pembinaan dan pendampingan usaha masyarakat. Sebab pendapatan menjadi kunci bagi mereka untuk mencukupi kebutuhan sehari-hari. Beragam kegiatan produksi yang telah dipaparkan sebelumnya menjadi gambaran umum bahwa masyarakat mengalami perubahan pola pikir dari mindset instan dalam menghasilkan pendapatan, menjadi mindset yang mau dan mampu berusaha/bekerja lebih giat lagi. Perubahan produktivitas masyarakat, lazimnya diikuti oleh perubahan pendapatan yang diperoleh, antara sebelum dan setelah menjadi warga binaan kampung topeng.

Berdasarkan penelitian yang dilakukan, masyarakat binaan telah mengalami perubahan penghasilan. Mereka telah mampu memperoleh pendapatan yang lebih baik dari sebelumnya. Hal ini disebabkan masyarakat mampu berusaha lebih baik dalam melakukan beragam pekerjaan. Pembinaan dalam upaya mengubah pola pikir masyarakat menjadikan mereka lebih mampu bekerja dengan giat dan aktif. Sebagaimana keluarga KK No. 15 yang mengalami peningkatan pendapatan dari pekerjaannya sebagai buruh bangunan, dibanding pekerjaan sebelumnya yang hanya memulung barang bekas. Pendapatan yang diperoleh mampu membuat keluarga tersebut menyekolahkan anak-anaknya, dan menghidupi kelima anggota keluarganya.

\section{2) Pengeluaran Masyarakat}

Pengelolaan pengeluaran juga berkaitan erat dengan dinamika kehidupan sosial ekonomi masyarakat. Pengeluaran yang dilakukan oleh warga binaan merupakan tindakan membelanjakan uang yang dimiliki untuk mencukupi kebutuhan hidupnya. Sebagaimana hasil penelitian, warga binaan sangat mengutamakan prioritas kebutuhan mereka, walaupun untuk kebutuhan primer telah mendapat bantuan dari pemerintah. Keterbatasan ekonomi membuat warga harus mampu memilah kebutuhan secara rasional.

Kebutuhan yang menjadi prioritas warga selain kebutuhan primer adalah biaya pendidikan anak dan modal usaha bagi warga yang konsisten berwirausaha. Kesadaran 
warga terhadap pendidikan anak sangat tinggi, meskipun mereka berada dalam keterbatasan. Dengan demikian, pengeluaran masyarakat untuk kebutuhan primer dapat diminimalkan dari adanya bantuan sosial, sehingga warga lebih mudah untuk mengupayakan biaya pendidikan bagi anak-anak mereka. Selain itu, mereka juga sedikit mampu memenuhi kebutuhan sekunder berupa kendaraan bermotor bekas untuk kemudahan mobilitas.

Selain pengelolaan terhadap kebutuhan primer dan biaya pendidikan anak, ada beberapa warga yang memprioritaskan pengeluaran untuk kelangsungan usaha mereka. Seperti KK No. 21 yang konsisten berjualan tahu tahwa, ronde, dan mie pangsit, juga KK No. 02 yang konsisten berjualan bakso. Meskipun pendanaan usaha telah mendapat bantuan dari pemerintah, jika tidak baik dalam mengelola modal tersebut, usaha mereka tidak akan berlanjut seperti beberapa warga yang tidak dapat menjalankan usahanya kembali. Kunci utamanya adalah kemampuan masyarakat dalam mengelola modal usaha.

Berdasarkan data yang diperoleh dari lapangan, dapat disimpulkan bahwa masyarakat binaan mengalami peningkatan ekonomi yang baik. Hal ini dilihat dari aktivitas konsumsi, produksi, dan pengelolaan keuangan, baik pendapatan ataupun pengeluaran yang dapat dikelola sesuai prioritas kebutuhan. Program pemberdayaan ekonomi ini telah membuat masyarakat mampu memperbaiki kehidupan sosial ekonominya dengan giat berusaha untuk mandiri.

\section{Transisi Kehidupan Ekonomi Masyarakat Wisata Kampung Topeng Malang}

Konsep ekowisata yang diterapkan pada pengembangan wisata kampung topeng dalam memberdayakan masyarakat tuna wisma bertujuan meningkatkan kesejahteraan masyarakat tersebut. Kunjungan para wisatawan diharapkan dapat memotivasi masyarakat binaan untuk membuka usaha/berwirausaha. Hal ini sebagaimana Herawati (2011) yang menemukan bahwa potensi atas pengembangan desa wisata dapat mengentaskan kemiskinan masyarakatnya.

Proram pemberdayaan ekonomi masyarakat tersebut telah memberikan bantuan rumah layak huni dan beberapa bantuan sosial lain untuk mencukupi kebutuhan pokok masyarakat binaan. Utamanya pemberian modal usaha untuk mendorong warga binaan dapat memperbaiki perekonomian mereka dengan berwirausaha. Hal tersebut diiringi dengan penyelenggaraan pelatihan dan pendampingan usaha yang dilaksanakan tim pengelola desa wisata untuk masyarakat binaan. 
Kusuma (2017) menemukan bahwa pengembangan desa wisata secara ekonomi dan sosial mampu memberikan kontribusi secara signifikan dalam meningkatkan ekonomi dan kesejahteraan masyarakat desa. Sebagaimana diupayakan Dinsos Kota Malang yang membina masyarakat tuna wisma yang direlokasi ke desa wisata. Pemberdayaan ekonomi yang dilakukan tersebut menyelenggarakan empat bidang penguatan, yaitu penguatan bidang ekonomi, bidang pendidikan, bidang kesehatan, dan bidang pembinaan mental spiritual. Upaya penguatan di atas oleh tim pengelola dilaksanakan dalam bentuk kegiatan-kegiatan yang melibatkan masyarakat secara langsung.

Di sisi lain pada proses awal relokasi dilakukan, warga binaan mengalami ketidaksiapan untuk berpartisipasi aktif dalam pengembangan desa wisata. Hal ini membuat konsep ekowisata yang direncanakan kurang sesuai dengan target yang diharapkan Dinsos dan tim pengelola. Dapat dikatakan, manfaat yang diharapkan belum nampak karena upaya yang dilakukan belum sesuai dengan kebutuhan masyarakat baru yang masih mengalami transisi dan adaptasi kehidupan ekonomi. Sebagaimana Horton (2011) yang menemukan bahwa menemukan bahwa program ekowisata disamping menawarkan peluang yang positif, namun ada juga dampak yang kurang menguntungkan masyarakat.

Fase adaptasi yang dialami warga binaan, baik adaptasi sosial, ekonomi, maupun lingkungan membuat kondisi mereka secara ekonomi masih fluktuatif. Hal ini membuat mereka membutuhkan waktu dan energi yang cukup untuk melalui masa transisi perpindahan tersebut. Kondisi tersebut membuat tujuan dari pengembangan ekowisata ini menjadi tampak bias. Sebab masyarakat lebih fokus pada adaptasi kehidupan sosial ekonominya, dibanding pengembangan desa wisata itu sendiri.

Fakta di atas membuat tujuan desa wisata yang diharapkan belum tercapai maksimal, karena pengembangan ekowisata tersebut bukanlah konsep yang diwujudkan dari sekedar potensi wisata, tetapi konsep yang diwujudkan sebagai upaya pemberdayaan masyarakat binaan. Hal ini membuat peran pemerintah lebih dominan, sebab pengembangan ekowisata tersebut ditujukan sebagai sarana implementasi program Desaku Menanti. Sebagaimana temuan Dewi (2013), yang menyatakan bahwa pengembangan desa wisata belum melibatkan masyarakat secara keseluruhan karena peranan pemerintah terlihat dominan.

Meskipun tampak fluktuatif, perubahan ekonomi masyarakat kampung topeng cukup dinamis. Hal ini terlihat dari aktivitas ekonomi msyarakat yang meliputi, kegiatan konsumsi, kegiatan produksi, dan kemampuan masyarakat dalam mengelola keuangan, baik pengelolaan pendapatan maupun pengeluaran. Sesuai dengan hasil penelitian yang telah dipaparkan, tiga aspek kegiatan ekonomi masyarakat mengalami perubahan yang lebih baik dari sebelum warga 
direlokasi dan dibina. Masyarakat melakukan kegiatan konsumsi dengan lebih rasional. Begitu juga dengan kegiatan produksi yang menjadi lebih aktif dan produktif melalui bermacam-macam usaha yang dilakukan untuk mendapatkan penghasilan yang lebih baik. Pengelolaan keuangan juga lebih menyesuaikan dengan prioritas kebutuhan. Pendapatan yang diperoleh dan pengeluaran yang dilakukan, disesuaikan dari kebutuhan yang paling prioritas. Utamanya kebutuhan primer, biaya pendidikan anak, dan pengembangan usaha. Walaupun di sisi lain warga belum mampu melakukan saving dengan rutin untuk kebutuhan masa depan.

Penyelenggaraan pelatihan dan pendampingan usaha bertujuan untuk meningkatkan potensi warga untuk berwirausaha dengan melihat peluang pasar (kunjungan para wisatawan). Agenda pelatihan ini dilaksanakan pemerintah dan tim pengelola untuk membantu masyarakat dalam beradaptasi secara ekonomi. Selain itu, warga binaan juga tidak dibatasi untuk mencari pekerjaan lain yang sesuai dengan kemampuannya. Pemerintah mengupayakan agar masyarakat mampu untuk mengubah pola pikir yang serba instan menjadi mampu berusaha secara mandiri. Semua itu tentu membutuhkan proses dan waktu yang tidak singkat. Melalui agenda pelatihan usaha ini diharapkan masyarakat dapat dibina dan diberdayakan menjadi lebih baik.

Berdasarkan atas analisis data yang telah dijelaskan, dapat disimpulkan bahwa tujuan dari program pemberdayaan ini $75 \%$ telah berjalan sebagaimana target yang diharapkan. Sedangkan $25 \%$ sisanya adalah masyarakat masih membutuhkan pembinaan dan pendampingan lebih lanjut mengenai konsistensi usaha yang dikembangkan. Presentasi ini tampak dari kemauan dan kemampuan masyarakat binaan untuk bekerja dan berusaha lebih giat dan tidak kembali mengamen atau meminta-minta di jalanan. Dengan itu, dapat diketahui bahwa masyarakat telah mengalami transisi kehidupan ekonomi menuju perbaikan kualitas hidup yang lebih baik. 


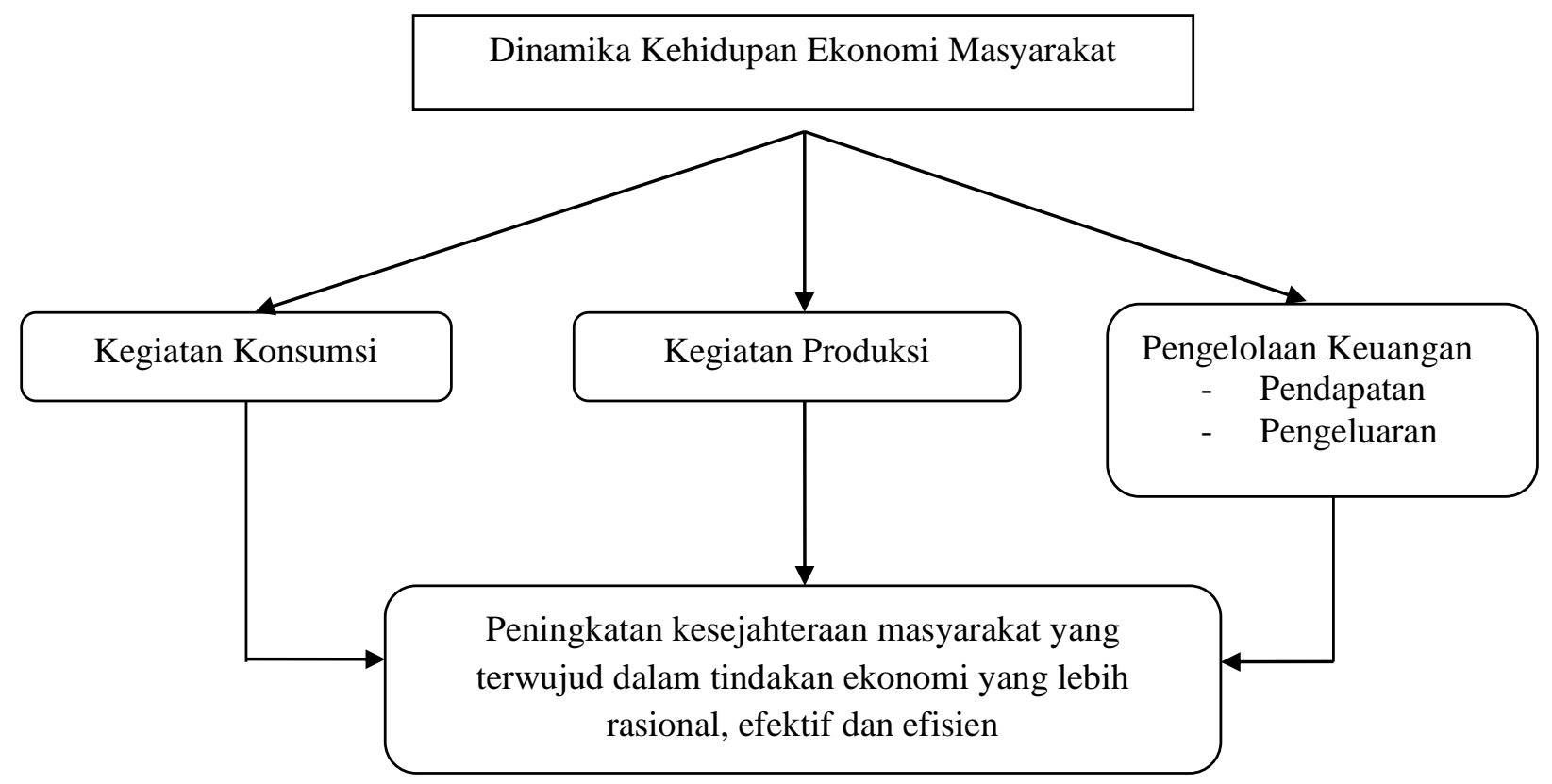

Gambar 1. Bagan Dinamika Kehidupan Ekonomi Masyarakat Kampung Topeng

\section{PENUTUP}

\section{Kesimpulan}

Program Desaku Menanti dari Kementerian Sosial RI telah diiplementasikan oleh Dinas Sosial Kota Malang dalam bentuk pengembangan desa wisata Kampung Topeng di Kelurahan Tlogowaru Kedungkandang Kota Malang. Desa wisata tersebut diwujudkan sebagai upaya pemberdayaan masyarakat tuna wisma yang terdiri atas pengemis, anak jalanan, pengamen, dan pemulung. Warga binaan tersebut diberikan beragam fasilitas dan bantuan sosial untuk mencukupi kebutuhan primernya. Disamping itu, mereka diberikan pembinaan dan pendampingan usaha dalam bentuk pelatihan dan pendanaan usaha mandiri.

Program pemberdayaan ekonomi masyarakat tersebut bertujuan untuk meningkatkan kesejahteraan masyarakat dan mampu berusaha menjadi mandiri dalam kegiatan ekonomi. Dalam proses pemberdayaan tersebut, masyarakat mengalami transisi kehidupan ekonomi. Beragam pekerjaan dan usaha yang telah mereka lakukan untuk meningkatkan kualitas hidup yang lebih baik. Masyarakat mampu menjadi lebih produktif dalam berusaha dan rasional dalam kegiatan konsumsi. Selain itu, kemampuan masyarakat dalam memprioritaskan kebutuhan tampak dalam pengelolaan keuangan yang lebih baik. 


\section{Rekomendasi}

Berdasarkan hasil penelitian yang telah ditemukan, ada tiga rekomendasi yang diberikan peneliti, diantaranya:

1) Hendaknya diagendakan event budaya Topeng Malangan sebagai bentuk publikasi Wisata Kampung Topeng kepada khalayak umum. Dengan ini, masyarakat luar dapat mengetahui adanya wisata ikon budaya Malang berbasis pemberdayaan masyarakat, sehingga dapat meningkatkan dukungan dan kunjungan wisatawan ke kampung wisata.

2) Pelaksanaan pelatihan dan pendampingan usaha perlu adanya spesialisasi kemampuan/keahlian yang sesuai dengan minat bakat masyarakat. Disamping itu, dibutuhkan wawasan kewirausahaan untuk meningkatkan pengetahuan, kemampuan, dan motivasi warga binaan dalam berwirausaha.

3) Perlu adanya agenda pelatihan manajemen keuangan untuk meningkatkan kemampuan masyarakat dalam pengelolaan modal usaha. 


\section{DAFTAR PUSTAKA}

Argyo, Dermatoto., dkk. 2009. Pembangunan Pariwisata Berbasis Masyarakat. Surakarta: Sebelas Maret University Press.

Bappenas. 2004. Rencana Strategi Penanggulangan Kemiskinan di Indonesia. Jakarta.

Bungin, Burhan. 2012. Analisis Data Penelitian Kualitatif. Jakarta: PT. RajaGrafindo Persada.

Das, Suchismita. 2011. Ecotourism, Sustainable Development and The Indian State. Economic and Political Weekly, 46(37), 60-67. Dari https://www.jstor.org/stable/23047281.

Dewi, Made Heny Urmila. 2013. Pengembangan Desa Wisata Berbasis Partisipasi Masyarakat Lokal di Desa Wisata Jatiluwih Tabanan, Bali. Jurnal Kawistara, 3(2), 117-226.

Departemen Kebudayaan dan Pariwisata. 2001. Tingkat Pemahaman Masyarakat terhadap Pembangunan Kepariwisataan di Indonesia. Jakarta: Departemen Kebudayaan dan Pariwisata.

Dwirianto, Sabarno.,dkk. 2014. Economic Empowerment Of Society Through Development Of Non-Formal Education Based On Life Skill Education In Pekanbaru City. IOSR Journal

Hill, Jennifer L. \& Hill, Ross A. 2011. Ecotourism In Amazonian Peru: Uniting Tourism, Conservation And Community Development. Geography, 96(2), 75-85.Dari https://www.jstor.org/stable/41320339.

Herawati, Tuty. 2011. Pemberdayaan Masyarakat Desa dan PenanggulanganMiskinan Melalui Pengembangan Desa Wisata di Depok. Jurnal Ekonomi Dan Bisnis, 10(2), 168-175.

Horton, Lynn R. 2009. Buying Up Nature: Economic and Social Impacts of Costa Rica's Ecotourism Boom. Latin American Perspectives, 36(3), 93-107. Dari https://www.jstor.org/stable/20684646.

Kusuma, Dedi Wijaya. 2017. Pemberdayaan Ekonomi Masyarakat Berbasis Potensi Lokal melalui Pengembangan Desa Wisata Lombok Kulon di Kabupaten Bondowoso. Disertasi tidak diterbitkan, Malang: Pascasarjana Universitas Negeri Malang.

Trisnawati, Aditya Eka. 2017. Pengembangan Desa Wisata \& Pemberdayaan Masyarakat Berbasis Potensi Lokal. Tesis tidak diterbitkan, Malang: Pascasarjana Universitas Negeri Malang. 